\title{
PERFORMANCE IMPROVED TRIANGULAR MULTI BAND ANTENNA USING REACTIVE IMPEDANCE SUBSTRATE AND FREQUENCY SELECTIVE SURFACE
}

\author{
K. Mahendran ${ }^{1}$, Dr. R. Gayathri ${ }^{2}$ \\ 1. Research Scholar, Dept. of ECE, Annamalai University, srimahendrancs@gmail.com \\ 2. Assistant Professor, Dept. of ECE, Annamalai University, gayathri_rajaraman@yahoo.co.in
}

\begin{abstract}
In modern world, communication devices need to be operated for more than one frequency bands. Lot of research works were carried out in the field of multiband antennas. The one major concern in the design of multiband patch antenna are the gain and bandwidth. Both gain and bandwidth of the multi band antenna can be improved for the better performance. In this paper a triangular multiband antenna is designed and the gain of the antenna is enhanced by the blend of reactive impedance surface and Frequency selective surface. The proposed antenna resonates $3.4 \mathrm{GHz}$, 4.2 $\mathrm{GHz}, 6.75 \mathrm{GHz}, 7.1 \mathrm{GHz}, 7.5 \mathrm{GHz}$ and $9.3 \mathrm{GHz}$ with a better return loss and gain.

Keywords:Triangular Microstrip Antenna (TMSA), Reactive Impedance Surface (RIS) Matematerial (MTM), Frequency Selective surface(FSS)
\end{abstract}

\section{INTRODUCTION}

\subsection{Multiband Antennas}

The development in communication system, provides opportunity for the researchers in developing antenna for multiple operating facility. These Modern antennas can resonate at multiple frequencies which can be used for variety of applications. The feature of patch antennas like low cost, low weight will facilitate the investigators to develop multiband operation in it. Multiband patch antennas are proficient to operate for more than one wireless communication standards in a single device. The multiple resonances are fashioned by making slots in either patch or ground plane [23-24].

\subsection{Triangular Microstrip Antenna (TMSA)}

The patch of the microstrip antenna come up with variety of shapes using variety of shapes like rectangular, triangular, circular, square, elliptical, annular ring, etc. The patch area required for Triangular patch is half of the area required by the rectangular patch antenna. Triangular patch antenna can be installed much easier in narrow space than rectangular patch. The dual and triple band operations can be implemented easily in Triangular patch antenna.

A CPW fed Triangular patch antenna with dual triangular slots was designed to operate on dual band frequencies was proposed [1]. A compact Fern fractal based Triangular patch antenna for vehicular communication was designed to operate at $5.88 \mathrm{GHz}[2]$. The Triangular patch antenna loaded with triangular meta surface was intended to operate over multiband operations was proposed [3]. An Equilateral Triangular

Copyright (C) Author patch antenna with Defected ground structure was proposed for Frequency reconfigurable operations [4]. The triangular patch structure was presented by Helszajn and James. The patch can be designed either in equilateral or right-angled triangle to form a TMSA. The Triangular patch antenna has very broad radiation characteristics [5].

\section{PERFORMANCE ENHANCEMENT OF PATCH ANTENNA}

The performance of the antenna can be enhanced by improving the parameters like return loss, gain and bandwidth. The techniques like incorporating the Metamaterials, Defected ground structure (DGS), Electronic Band gap structure (EBG), Reactive impedance structure (RIS), Frequency selective surfaces (FSS), Partially reflective surfaces (PRS), Artificial magnetic (AMC) etc., are proposed to enhance performance of the antenna. This paper presents the use of Reactive impedance surface and Frequency selective surfaces to improve the performance of the antenna.

\subsection{Reactive Impedance Surface (RIS)}

A periodic arrangement of metallic shapes over the grounded dielectric substrate forms a structure called Reactive impedance surface. The artificial created periodic arrangement of unit cells, forms the Reactive impedance surfaces. This unit cells produce capacitive impedance. RIS layer is placed above the ground plane with a minimal distance (height of the substrate) yield inductive property. The desired impedance of the patch is obtained with the help of this inductive and capacitive impedances. In order to obtain the desired performance, 
the Reactive Impedance Surface can be tuned anywhere between PEC and PMC surfaces. The interaction between the patch and substrate is curtail by RIS layer. The impedance of the RIS can be obtained by

$$
\begin{aligned}
& Z_{r i s}=\frac{X_{L} X_{C}}{X_{L}-X_{C}} \\
& X_{L}=j Z_{d} \tan k_{o} \sqrt{\varepsilon_{r}} h_{2} \\
& X_{C}=\frac{1}{j \omega C_{r i s}}
\end{aligned}
$$

$Z_{\text {ris }}-$ Reactive impedance of RIS

$X_{L}, X_{C}$ - Inductive and capacitive impedance of RIS

The bandwidth can be widened by using inductive impedance of RIS and miniaturization of the antenna can be done using capacitive impedance of RIS. A multiband metamaterial-based antenna was designed and the performance was enhanced using RIS [6]. A Meandered line shaped RIS was used as a ground plane for MPA, which facilitates miniaturization of the antenna [7]. To enhance the radiation characteristics of antenna a multi stacked patch with RIS was designed to operate over triple band frequency [8]. A bandwidth enhanced miniaturized patch antenna using RIS and coplanar parasitic patches was proposed and designed [9]. A high gain wideband array antenna was designed and the performance was improved using RIS and Fabry perot cavity resonator [10-11].A H- shaped Reactive impedance surface was loaded with Koch fractal patch for S and C band applications was presented [12]. A multiband antenna performance was enhanced using RIS layer was presented [13].

\subsection{Frequency Selective Surface (FSS)}

Frequency selective surfaces are also called as meta surfaces. These meta surfaces are built over the patch with minimal airgap. The surfaces permit or block the electromagnetic waves with respect to the frequency. Due to this Frequency selectiveness property this structure is also called spatial filters. The array of periodically arranged unit cells forms FSS layer. The meta surfaces are high impedance surfaces that are incorporated over the dielectric slab. Meta surfaces exhibits either transmission or reflection properties with respect to the arrangement of unit cells.

Resistive and inductive impedance on the surface are created by the unit cells and the gaps between the unit cells offers capacitive impedance.

During the EM wave transmission, the unit cells will act as equivalent resonance circuit. The frequency of resonance is given as

$$
f_{r=\frac{1}{2 \pi \sqrt{L C}}}
$$

The gain enhanced Multipattern FSS based reconfigurable antenna was proposed and designed [14]. A compact dual band antenna with single layered FSS was proposed and the gain of the antenna was improved over 50\% [15]. A triple band antenna with single layer FSS was demonstrated to get high directional characteristics [16]. Transmission properties of FSS based Multiband Fractal antenna was described [17]. Design of High gain wideband resonator cavity antenna using FSS was proposed [18]. A metamaterial based dual band antenna was designed and the gain of the antenna improved with the help of FSS [19]. An improved gain metamaterial superstrate based dual band antenna was proposed and designed [20]. A dual ring shaped FSS was incorporated over rectangular patch to enhance the gain and bandwidth of the antenna [22]. A square slot with stub shaped FSS was intended over rectangular patch to provide multi band operations [22].

\section{ANTENNA DESIGN}

This paper presents a triangular patch antenna with triangular spilt ring resonator. The performance of the designed antenna was improved with the help of reactive impedance surface and frequency selective surfaces. The combination of RIS and FSS layer is proposed. The proposed antenna, has the geometry of $50 * 30 * 1.6 \mathrm{~mm}^{3}$, which is shown in Figure 1. The antenna designed using FR4 material with relative permittivity of 4.4 , loss tangent of 0.02 and thickness of $1.6 \mathrm{~mm}$. The antenna is fed with $50 \Omega$ microstrip line. The antenna was designed in 3D EM simulation tool. The dimensions of proposed antenna are listed in the Table 1.

Table 1 Design parameters of proposed antenna

\begin{tabular}{|c|c|c|c|}
\hline Parameter & $\begin{array}{c}\text { Value } \\
(\mathbf{m m})\end{array}$ & Parameter & $\begin{array}{c}\text { Value } \\
(\mathbf{m m})\end{array}$ \\
\hline $\mathrm{L}$ & 50 & $\mathrm{~W}_{2}$ & 0.2 \\
\hline $\mathrm{W}$ & 30 & $\mathrm{~L}_{3}$ & 2.8 \\
\hline $\mathrm{L}_{1}$ & 22.8 & $\mathrm{~W}_{3}$ & 0.3 \\
\hline $\mathrm{W}_{1}$ & 3.05 & $\mathrm{a}$ & 26.4 \\
\hline $\mathrm{L}_{2}$ & 5 & $\mathrm{a}_{2}$ & 6.5 \\
\hline
\end{tabular}

The design flow of antenna as follows. First the triangular patch antenna with triangular split ring resonator was designed. The design equations of the triangular patch antenna is listed below. The schematic of triangular patch antenna is represented in figure 1 . 


$$
a=\frac{2 c}{3 f_{r} \sqrt{\varepsilon_{e f f}}}
$$

" $\varepsilon_{\text {eff }}$ " is effective dielectric constant, and this can be found using

$$
\varepsilon_{e f f}=\frac{\left(\varepsilon_{r}-1\right)}{2}+\frac{\left(\varepsilon_{r}-1\right)}{4}\left[1+\frac{12 w}{h}\right]^{-(1 / 2)}
$$

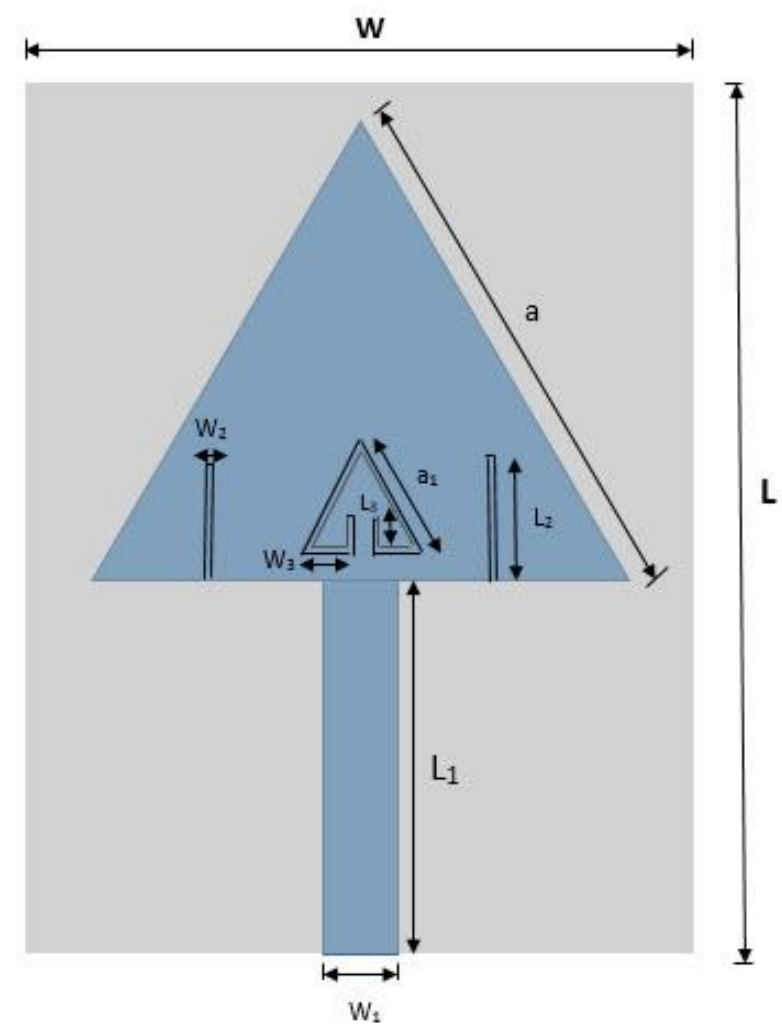

Fig. 1 Schematic of the proposed TMSA

To enhance the performance of the antenna, a reactive impedance surface was introduced between patch and ground plane and a Frequency selective surface was introduced above the patch. The cross-section view of the proposed antenna is shown in the figure 2 .

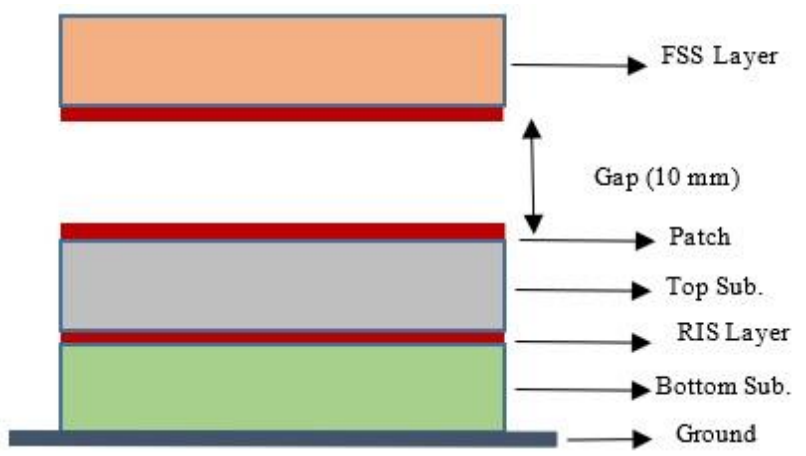

Fig. 2 Cross sectional view of proposed antenna
The proposed structure has 2 substrate each has the height of $1.6 \mathrm{~mm}$. RIS layer has formed on top of the bottom substrate. The triangular patch is positioned over the top substrate and ground plane is positioned below the bottom substrate. The FSS layer formed above the triangular patch with minimal air gap of $10 \mathrm{~mm}$.

Both RIS and FSS structures are formed using array of unit cells with equal spacing. The cross shaped unit cell is introduced in the proposed system which is represented in the figure 3 .

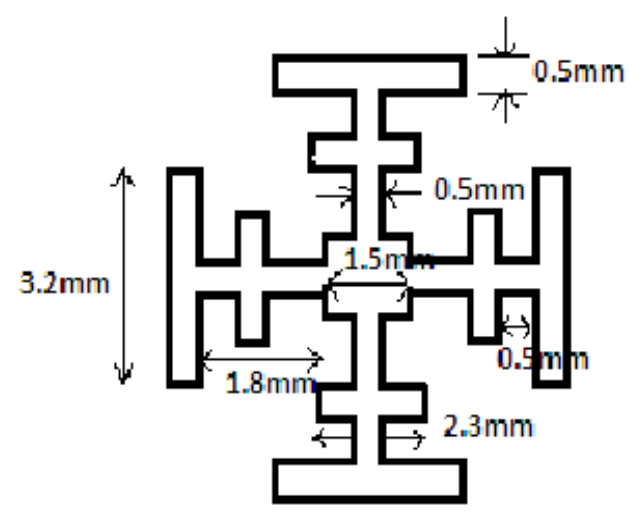

Fig. 3 Structure of unit cell.

Array is formed using $4 * 3$ unit cells as represented in the figure 4 . This array is used to form FSS and RIS layer. The FSS layer modify the radiation characteristics of the patch using partial reflection property and RIS layer decreases the coupling between patch and ground plane. There by this combination alters and improve radiation characteristics of the antenna. 


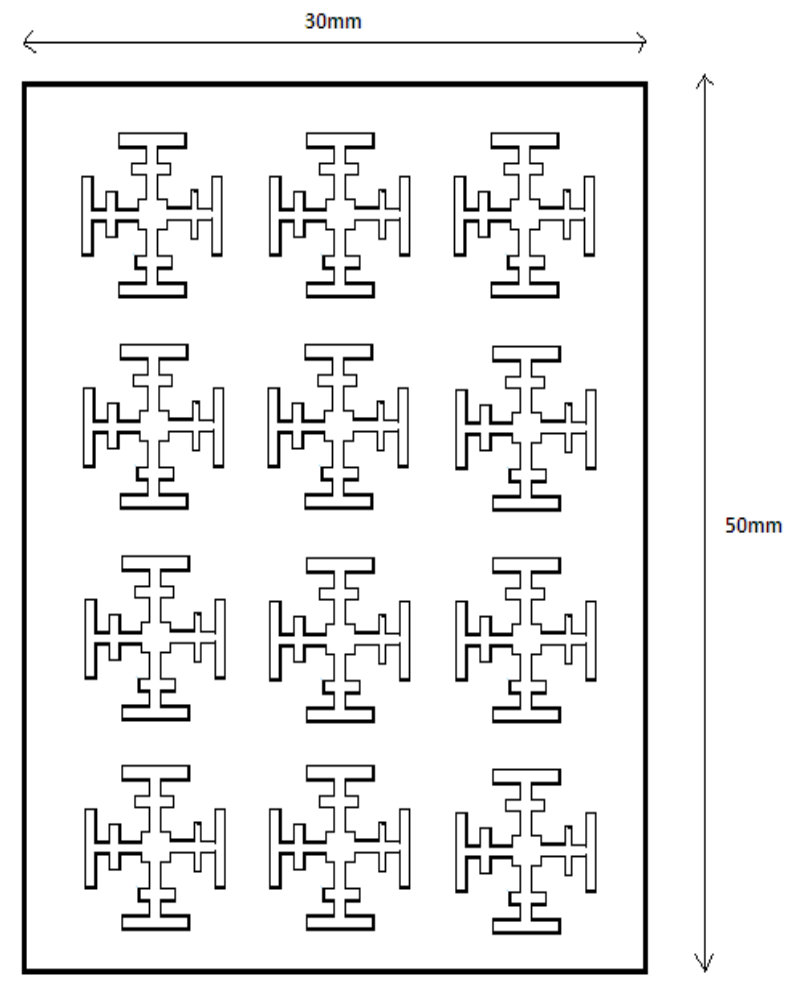

Fig. 4 Structure of RIS and FSS Layer

\section{RESULTS AND DISCUSSION}

The return loss and VSWR of the proposed antenna both stimulated and measured results are represented in the figure 5 and 6 . Both the stimulated and measured results are similar to each other.

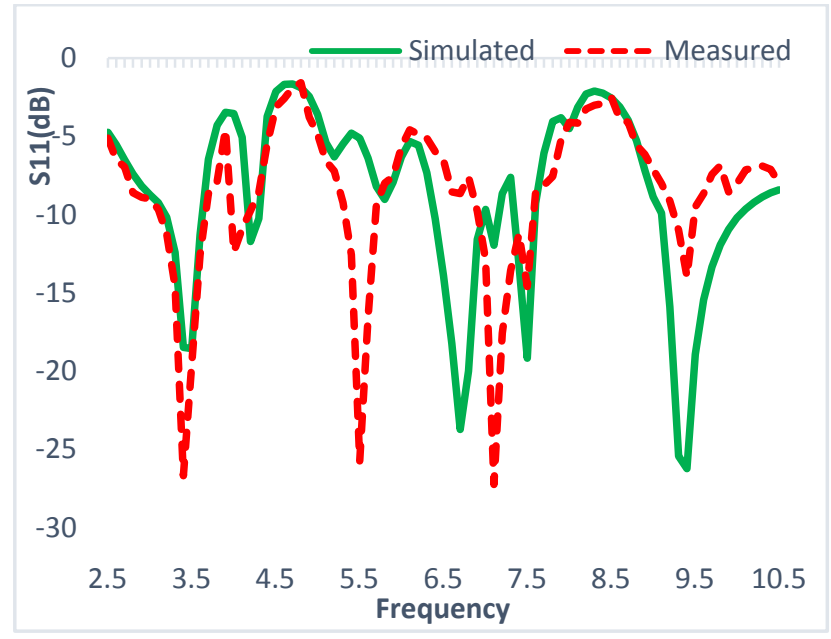

Fig. 5 Return loss of the Proposed Antenna both simulated and measured

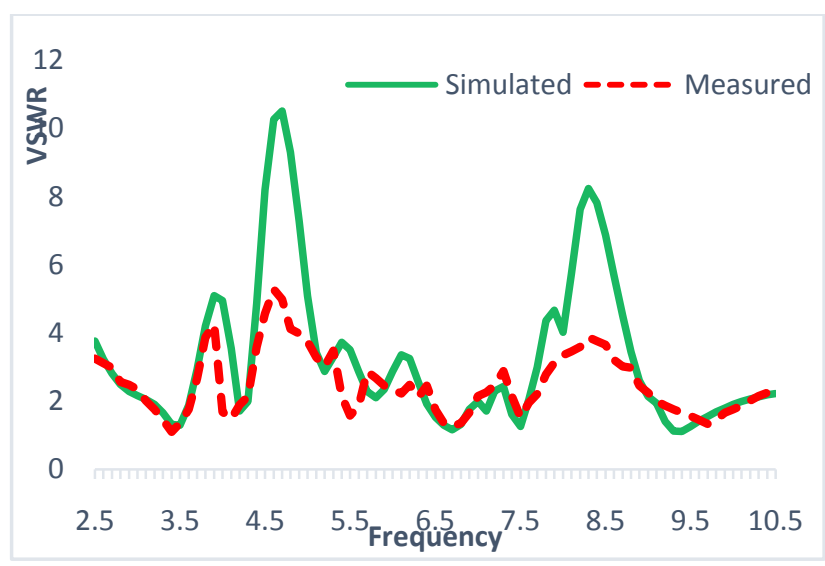

Fig. 6 VSWR of the Proposed Antenna both simulated and measured

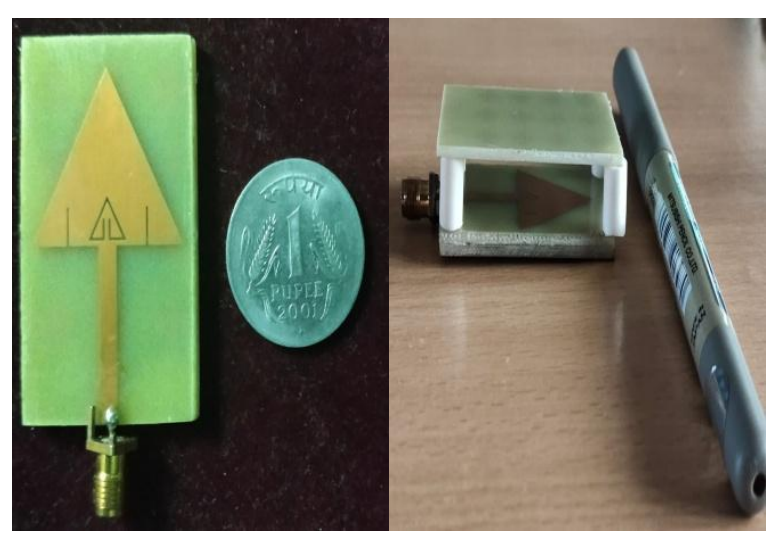

Fig. 7 patch structure and cross-sectional view of fabricated prototype

To ensure the results the antenna is fabricated and then tested using Agilent Vector Network Analyzer (VNA). The patch and cross-sectional view of the prototype is represented in figure 7.

The $\mathrm{E}$ and $\mathrm{H}$ plane radiation characteristics of the proposed antenna is illustrated in Figure $8 \& 9$. The designed antenna gives omni directional radiation characteristics and radiations are also stable in desired bands. 


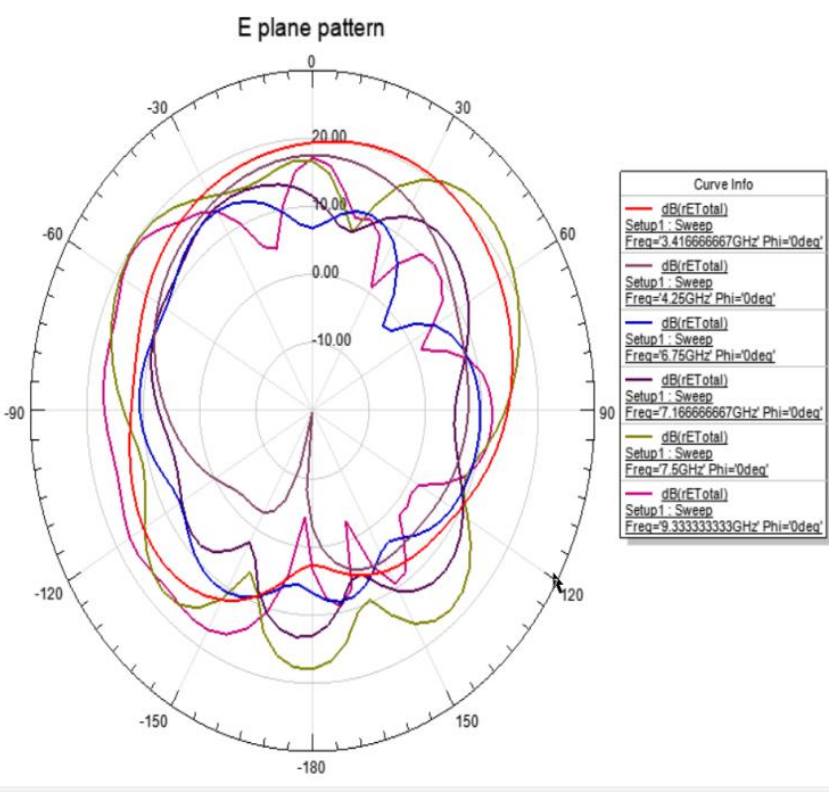

Fig. 8 E- plane Radiation Characteristics for all six operating bands

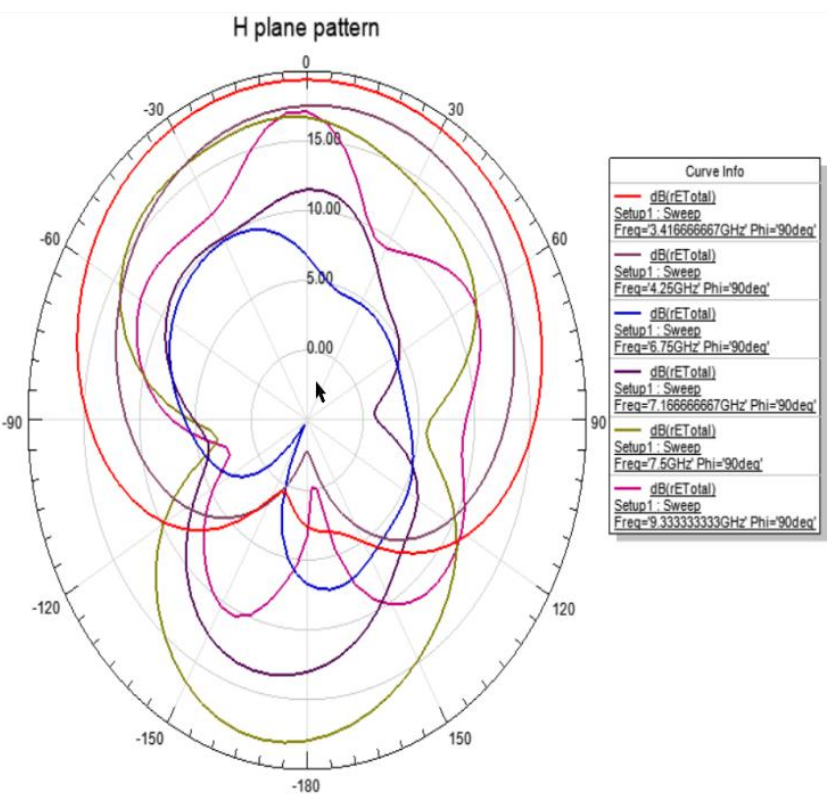

Fig. 9 H- plane Radiation Characteristics for all six operating bands

Table 2Comparison with previous works

\begin{tabular}{|l|l|l|l|l|l|}
\hline Ref. & $\begin{array}{l}\text { Size of } \\
\text { the } \\
\text { anten } \\
\text { na }\end{array}$ & $\begin{array}{l}\text { Frequenc } \\
\text { y bands } \\
\text { covered } \\
(\mathbf{G H z})\end{array}$ & $\begin{array}{l}\text { Anten } \\
\text { na } \\
\text { type }\end{array}$ & $\begin{array}{l}\text { Peak gain } \\
(\mathbf{d B})\end{array}$ & $\begin{array}{l}\text { Application } \\
\text { s covered }\end{array}$ \\
\hline$[1]$ & $\begin{array}{l}42 * 4 \\
6\end{array}$ & $3 / 4.4$ & Dual & $1.8 / 2.6$ & $\begin{array}{l}\text { GSM/ } \\
\text { Satellite } \\
\text { Comm. }\end{array}$ \\
\hline$[3]$ & $\begin{array}{l}30 * 4 \\
0\end{array}$ & $\begin{array}{l}6.6 / 9.2 / 10 . \\
9 /\end{array}$ & $\begin{array}{l}\text { Multib } \\
\text { and }\end{array}$ & $\begin{array}{l}3.4 / 3.7 / 8.8 / \\
6.1 / 4.4\end{array}$ & $\begin{array}{l}\text { X band } \\
\text { satellite }\end{array}$ \\
\hline
\end{tabular}

\begin{tabular}{|c|c|c|c|c|c|}
\hline & & $11.5 / 11.9$ & & & $\begin{array}{l}\text { comm./ } \\
\text { Defence } \\
\text { applications }\end{array}$ \\
\hline [4] & $\begin{array}{l}80 * 1 \\
00\end{array}$ & $1.93 / 3.7$ & $\begin{array}{l}\text { Dual } \\
\text { band }\end{array}$ & $2 / 2.4$ & $\begin{array}{l}\text { L band } \\
\text { Satellite } \\
\text { comm. / 4G } \\
\text { comm. }\end{array}$ \\
\hline [5] & $\begin{array}{l}24 * 2 \\
7\end{array}$ & $\begin{array}{l}1.7 / 2.04 / 2 \\
16 / 2.25\end{array}$ & $\begin{array}{l}\text { Multib } \\
\text { and }\end{array}$ & $\begin{array}{l}5.1 / 5.86 / 6.2 \\
/ 6.3\end{array}$ & $\begin{array}{l}\text { GSM, S } \\
\text { band satellite } \\
\text { comm. }\end{array}$ \\
\hline [7] & $\begin{array}{l}80 * 8 \\
0\end{array}$ & $\begin{array}{l}1.17 / 1.22 / \\
1.57\end{array}$ & Triple & $\begin{array}{l}0.73 / 1.1 / \\
3.3\end{array}$ & $\begin{array}{l}\text { GPS } \\
\text { applications }\end{array}$ \\
\hline [8] & $\begin{array}{l}64 * 6 \\
4\end{array}$ & $\begin{array}{l}2.38 / 2.68 / \\
2.98 / 3.18\end{array}$ & $\begin{array}{l}\text { Multib } \\
\text { and }\end{array}$ & $\begin{array}{l}4.3 / 4.5 / 5.6 / \\
5.4\end{array}$ & $\begin{array}{l}\mathrm{S} \text { band } \\
\text { wireless } \\
\text { comm. }\end{array}$ \\
\hline [11] & $\begin{array}{l}36 * 3 \\
6\end{array}$ & $3.4 / 5.35$ & Dual & $3.9 / 1.84$ & $\begin{array}{l}\text { Air borne } \\
\text { SAR system }\end{array}$ \\
\hline [12] & $\begin{array}{l}100^{*} \\
100\end{array}$ & $2.45 / 3.5$ & Dual & $8.4 / 7.9$ & $\begin{array}{l}\text { Vehicular } \\
\text { Comm. }\end{array}$ \\
\hline [13] & $\begin{array}{l}36 * 3 \\
8\end{array}$ & $2.4 / 5$ & Dual & - & WLAN \\
\hline [18] & $\begin{array}{l}56 * 5 \\
6\end{array}$ & $2.4 / 3.5$ & Dual & $3.2 / 2.5$ & $\begin{array}{l}\text { WIFI/ } \\
\text { WiMAX }\end{array}$ \\
\hline $\begin{array}{l}\text { prop } \\
\text { osed }\end{array}$ & $\begin{array}{l}30 * 5 \\
0\end{array}$ & $\begin{array}{l}3.4 / 4.2 / 6.7 \\
/ 7.1 / 7.5 / \\
9.3\end{array}$ & $\begin{array}{l}\text { Multib } \\
\text { and }\end{array}$ & $\begin{array}{l}3.4 / 1.62 / \\
0.4 / 0.6 \\
1.79 / 2.08\end{array}$ & $\begin{array}{l}\text { WiMAX/ } \\
\text { radio } \\
\text { altimeter } \\
\text { /RADAR/ X } \\
\text { band } \\
\text { wireless } \\
\text { applications }\end{array}$ \\
\hline
\end{tabular}

Table 3 Concluding summary Table

\begin{tabular}{|c|c|c|c|c|c|c|c|}
\hline \multirow{3}{*}{$\begin{array}{c}\text { Wit } \\
\text { h } \\
\text { RIS } \\
\& \\
\text { FSS }\end{array}$} & $\begin{array}{c}\text { Resonant } \\
\text { Frequenc } \\
\mathrm{y}\end{array}$ & 3.4 & 4.2 & 6.75 & 7.16 & 7.5 & 9.3 \\
\hline & $\begin{array}{l}\text { Return } \\
\text { Loss }\end{array}$ & $\begin{array}{c}- \\
13 . \\
7\end{array}$ & $\begin{array}{c}- \\
14.2 \\
9\end{array}$ & $\begin{array}{c}- \\
25.6 \\
3\end{array}$ & $\begin{array}{c}- \\
12.0 \\
6\end{array}$ & $\begin{array}{c}- \\
35 . \\
5\end{array}$ & $\begin{array}{c}- \\
34 . \\
4\end{array}$ \\
\hline & $\begin{array}{l}\text { Gain } \\
\text { (in dB) }\end{array}$ & 3.4 & 1.62 & 0.40 & 0.60 & $\begin{array}{c}1.7 \\
9\end{array}$ & $\begin{array}{c}2.0 \\
8\end{array}$ \\
\hline
\end{tabular}

\section{SUMMARY}

A Triangular shaped patch antenna for multiband applications is proposed and designed. The performance enhancement is done by the combination of Reactive impedance surface and Frequency selective surfaces. The proposed antenna operates over six resonances with better return loss and gain. 


\section{ACKNOWLEDGMENT}

The first author wishes to thank the authorities of Annamalai University for their encouragement and support in pursuing Research work. First author also like to thank the authorities of CK College of Engineering and Technology for allowing me to carry out the research work.

The second author wishes to thank her Guru Dr.K.K.Sood, Deputy Director, Space Application center, ISRO, Ahmedabad.

\section{References}

[1] K. Satya Ramesh, A.S.D Sravani, M. Kokila, V. Heeraja, B. Nishanth, M. Suman, Prasanth Mankar "Design of Dual band Triangular patch with Triangular slot antenna for Satellite Applications", Journal of Critical Reviews., Vol. 7, No.7, 2020.

[2] Tapas Mondal, Sanya suman, Shibu Singh "Novel Design of Fern Fractal based Triangular patch antenna", IEEE Xplore, June 2020.

[3] Apartim Chatterjee, Dweepayan Sen Sharma, Diptiranjan Samantaray, Chittajit Sarkar, Chinmoy Saha, Somak Bhattachariya , "Design of Printer Triangular Patch Antenna Loaded with Novel TridentShaped met surface and Defected Ground Plane", URSI RCRS, June 2020.

[4] Murali Krishna Bonthu, Ashish Kumar Sharma "Design and Analysis of Frequency Reconfigurable Equilateral Triangular Microstrip Patch Antenna", ECTI-CON, IEEE Xplore, August 2020.

[5] M. Arulaalan, K. Mahendran, G. Maikannan and P. Prabakaran, "Design of MIMO Triangular Microstrip patch antenna for IEEE 802.11a Application", Inventive communication and computational Technologies Lecture notes in Networks and systems, 2020.

[6] N.Ramya M.Sujatha T.Jayasankar Prasad Jones Christydass, "Metamaterial Inspired Circular Antenna with DGS for Tetra Band Application", International Journal of Control and Automation, Vol. 13, No. 2, (2020), pp. $877-882$.

[7] Anumoy Ghosh, Arijit Mitra, Santanu Das "Meandered Line based Low Profile RIS With Defected Ground and its use in patch Antenna Miniaturization for Wireless Applications", Microwave and Optical Technology Letters, Vol.59. No.3, March 2017.

[8] Kush Agarwal, Nasimuddin, Arokiaswami Alphones "Triple-band Compact Circularly Polarized Stacked Microstrip Antenna over Reactive Impedance Metasurface for GPS Applications", IET Microwaves, Antennas and Propagation, April 2014.

[9] Fanji Meng, Ying Liu, Satish K. Sharma "A Miniaturized Patch Antenna with Enhanced Bandwidth by using Reactive Impedance Surface ground and coplanar parasitic patches", $R F$ and
Microwave Computer Aided Engineering, Wiley, February 2020.

[10] Sneha Dalvi, Shishir Jagtap, Vijaypal Yadav, Rajiv Kumar Gupta "High Gain Wideband 2*2 Microstrip Array Antenna using RIS and Fabry Perot Cavity Resonator", IEEE 2016.

[11]P.Maheswara Venkatesh, T.Jayasankar, K.Vinoth Kumar, "Inverted S-Shaped Quad Band Patch Antenna for Wireless Applications," Journal of Advances in Chemistry, Vol 12, No 1 9, Nov 2016, pp 5139-5144

[12] Galaba Sai Rajesh and Vijayakumar, "H-RIS Inspired Koch Fractal Antenna for $\mathrm{S}$ and $\mathrm{C}$ band SAR Applications, Microwave and Optical Technology Letters, Vol.58. No.6, June 2016.

[13]K. Mahendran, Dr. R. Gayathri, "Performance Enhancement of Multiband Triangular Microstrip patch antenna using Reactive Impedance Substrate". High Technology Letters, Vol. 26, No.12, 2020.

[14]Balu Ashvanth, Bactavacahalame Partibane, Mohamed Gulam Nabi Alsath, Rajakani Kalidoss "Gain Enhanced Multi pattern Reconfigurable antenna for Vehicular Communications", $R F$ and Microwave Computer Aided Engineering, Wiley, February 2020.

[15]R. Adeline Mellita, D.S. Chandu, S. S. Karthikeyan "A Compact Dual Band Frequency Selective Surfaces for Gain Enhancement of a dual band antenna", Optical and Wireless Ethnologies, Springer electrical Series, 2018.

[16]H. So, A. Ando, T. Seki, M. Kawashima and T. Sugiyama, "Directional Multiband Antenna employing Frequency selective surfaces", Electronic Letters, Vol.49, No.4, February 2013.

[17] Wang Shanshan, Gao Jinsong, Xu Nianxi "Transmission Properties Multi band FSS based Fractal Elements", IEEE 2010.

[18] Mojtaba Simruni, Shahrokh Jam, "Design of High gain Wideband Microstrip Resonant Cavity Antenna using FSS superstrate with Equivalent Circuit Model", International journal of Electronics and Communications, Elsevier 2019.

[19] Safiullah Khan, Thomas F. Eibert, "A MultiFunctional Metamaterial based dual band isotropic Frequency Selective Surface", IEEE Transactions on Antenna and Propagation 2018.

[20]Zain Haider, Muhammad U. Khan, Hammed M. Cheema, "A dual band Zero Index Metamaterial superstrate for Concurrent antenna Gain Enhancement at $2.4 \mathrm{GHz}$ and $3.5 \mathrm{GHz}$ ", IETE Journal of Research, March 2020.

[21]Hsing-Yi Chen, Yu Tao, "Antenna Gain and Bandwidth Enhancement using Frequency Selective Surfaces with double Rectangular Ring Elements", IEEE 2010.

[22]B. Rahmati, H.R. Hassani "Multiband Metallic Frequency Selective Surface with wide range of Band Ratio", IEEE Transactions on Antenna and Propagation 2015. 
[23] R. Gayathri, M. Anitha, KK sood, "Wideband Gain Enhanced Miniaturized Metamaterial based antenna for wireless application", International journal of Inventive Engineering and science, Vol. 3, No. 1, 2014.

[24] S.Shanthi, T. Jayasankar, Prasad Jones Christydass, P. Maheswara Venkatesh, "Wearable Textile Antenna For GPS Application", International Journal of Scientific \& Technology Research, Vol.8, No.11, pp.3788-3791, Nov 2019.

[25]

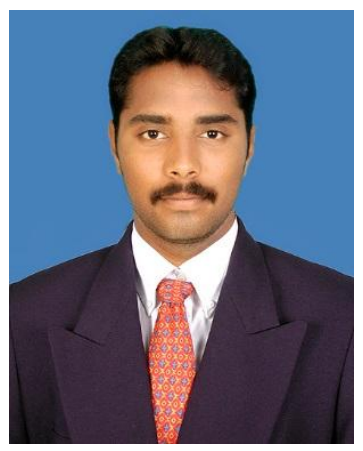

Mr. K. Mahedran received his B.E (ECE) degree from Anna University, India. He received M.E (Communication Systems) degree from Anna University, India. He currently working as Assistant Professor in Manakula Vinayagar Institute of Technology, Puducherry, India. He is pursuing his Ph.D. (research work) in Annamalai University, India under the supervisorship of Dr. R. Gayathri. His research interest includes Antennas, Image Processing, Communication Engineering and optical Communication.

Email: srimahendrancs@gmail.com

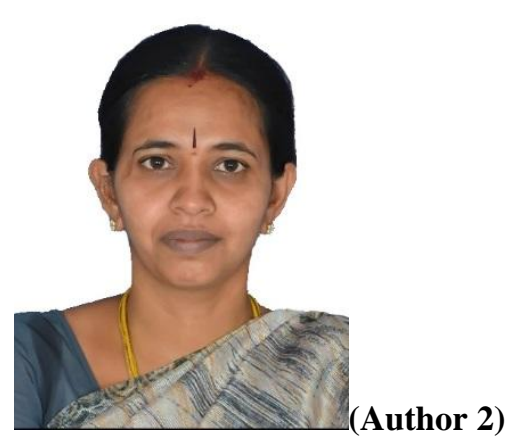

Dr. R. Gayathri currently working as Assistant Professor of ECE, in Annamalai University, India. She has authored several papers in indexed International Journal and Conferences. Her area of interest includes Microwaves, Antennas, Image Processing and Networks. She is reviewer of reputed international journals.
Email: gayathri_rajaraman@yahoo.co.in. 